\title{
INTEGRATION OF SOCIAL INNOVATION CREATION IN HIGHER EDUCATION FOR ENHANCING OF ECONOMIC DEVELOPMENT IN LATVIA
}

\author{
Gunta Grinberga-Zalite, Gunita Mazure \\ Latvia University of Agriculture \\ gunta.grinberga@1lu.lv,gunita.mazure@1lu.lv
}

\begin{abstract}
Lately, the European Commission has developed a number of policies, programmes and initiatives that have contributed to empowering citizens and organisations to address social issues, and the new European strategic framework for 2014-2020 focuses on intelligent, durable development. The article describes the role of social innovation in the European Union and presents a study of the main approaches for enhancing the creation of social innovation in Latvia. The aim of the paper is to provide an overview of social innovation implementation through higher education institutions as education is an essential prerequisite for economic development and achieving higher standard of living. The current research employed monographic method, analysis and synthesis, as well as scientific induction and deduction methods to summarize the theoretical findings and basic guidelines of strategic documents, thus developing an extensive discussion on the problems how to motivate young society to get more actively involved in solving of social problems. The current research is a continuation of several related research projects implemented in scope of the National Research Program 5.2. EKOSOC-LV "Involvement of the Society in Social Innovation for Providing Sustainable Development of Latvia". The study shows that in Latvia's situation the society has many obstacles to use opportunities of bottom-up approach, thus giving preference to top-down approach relying rather on top-down scenario than on self-initiated scenario of social innovation creation. Consequently, it is important to integrate social awareness in higher education by strengthening the collaboration among education, state institutions and business entities, thus more efficiently involving students in searching solutions to really existing and topical social problems in Latvia.
\end{abstract}

Keywords: social innovation, higher education, economic development.

\section{Introduction}

Since 2009, an increasing number of discussions on social innovation initiatives and their implementation opportunities in the Member States have taken place at the European Commission level. Social innovation has been promoted as the solution to the growing social needs, and as an innovative solution for those issues that require structural changes to promote the welfare of the population and more efficient use of financial resources. Although scientific literature analysis reflects many different views on the definition of the term "social innovation", its role is gradually growing in the discussions on the EU policy priorities. This is evidenced by the fact that social innovation is one of the "Europe 2020" strategy's seven flagship initiatives that the European Commission has drawn up to determine the national, European and international measures that would be implemented in the field of innovation in order to achieve the goals set by the "Europe 2020" strategy. Moreover, special attention to the social innovation is provided in scope of the European Union's initiative "Innovation Union", which emphasizes the need to incorporate social innovation support measures for the European Social Fund programmes in 2014-2020 [1]. Also at Latvia's level, in 2014 experienced and young scientists from the leading higher education institutions were involved in a national research project "Involvement of the Society in Social Innovation for Providing Sustainable Development of Latvia (EKOSOC-LV)" aimed to work out the methodology and basis for conducting the empirical research in order to reveal the character of social innovation processes in the Latvian society for elaborating a model of active involvement of different stakeholders in social innovation. The current project provides active collaboration of four important stakeholders of social innovation promotion society, policy makers, entrepreneurs and higher educational establishments. In the previous research works, project group conducted studies on the development of social innovation in various industries, on promotion models of social innovation and conducted benchmarking studies on successful innovation development abroad. The current study is a continuation of these related research series that will focus on the role of higher education institutions (HEIs) in enhancing social awareness that is an important prerequisite for the developing social innovation in Latvia. The aim of the research was to analyse the opportunities for integrating social innovation in higher education studies. The specific research tasks were: 1) to reflect the topicality of social innovation for enhancing the economic development; 2) to justify the HEIs need to engage in the promotion of social innovation; 3 ) to analyse 
opportunities for enhancing students' social awareness and motivation to involve in creation of social innovation.

\section{Materials and methods}

The current research employed monographic method, analysis and synthesis, as well as scientific induction and deduction methods to summarize the theoretical findings and basic guidelines of strategic documents, thus developing an extensive discussion on the problems how to motivate young society to get more actively involved in solving of social problems. To obtain detailed opinion of social innovation project implementers, the authors conducted in-depth interviews with 10 project leaders that represented various industries, in which they had developed their social innovation idea real estate management, charity activities, social entrepreneurship involving disabled people, exchange of professional services based on time sharing principles, innovative organizational models of agricultural production and distribution etc.

\section{Results and discussion}

Social innovation means developing new ideas, services and models to better address social issues. It invites input from public and private actors, including civil society, to improve social services [2]. A key difference of the rest of the business innovations from the social innovation is a focus on profit maximization. Behind business innovation usually stands targeted investor, but social innovation requires different and diverse set of support resources, including policy makers' recognition and support, and often volunteering and charity [3]. According to European Commission [2] and Bonifacio [4], there are three key approaches to social innovation.

- The social demand approach (the "ghetto" view), which responds to social demands that are traditionally not addressed by the market or existing institutions and are directed towards vulnerable groups in society. They have developed new approaches to tackling problems affecting youth, migrants, the elderly, socially excluded etc.

- The societal challenge approach (the "reformist" view) focuses on innovations for society as a whole through the integration of the social, the economic and the environmental. Societal challenges in which the boundary between 'social' and 'economic' blurs, and which are directed towards society as a whole.

- The systemic change approach (the "empowering" view), the most ambitious of the three and to an extent encompassing the other two, is achieved through a process of organizational development and changes in relations between institutions and stakeholders. The process of reforming society in the direction of a more participative arena where empowerment and learning are sources and outcomes of well-being [5].

The concept social innovation is closely linked with the social economy development, which is defined as a third sector among economies between the private and public sectors, which is based on democratic values, and seeks to improve social, economic and environmental conditions in a given society [6]. It includes organizations such as foundations, cooperatives, non-profit organizations, social enterprises and charities; social economy becomes more significant in Europe [7]. It is because social economy promotes fulfilment of societal aims and has potential to create common wealth by producing goods and delivering services. Currently, social economy is still regarded as a new sector, which is facing a number of challenges, for example, lack of specific corresponding regulations, incomprehension within society and businesses about the core idea and functioning of social enterprises, lack of wider social recognition of this form of economic activity. Thus, social economy faces many barriers in its development. The European Commission has developed a number of policies, programmes and initiatives that have contributed to empowering citizens and organisations to address social issues [8], policy-makers explore ways to foster social innovation in order to achieve economic growth. The new European strategic framework for 2014-2020 focuses on intelligent, durable development, favourable to inclusion. This can be achieved by target-oriented state policy aimed at supporting social innovation because the main initiator of social innovation promotion is government that ensures particular support instruments (financial, legal, informative etc.) for promoters and implementers of social innovation [1]. 
The in-depth personal interviews that were conducted from November 2016 until February 2017 by the authors in scope of the EKOSOC-LV project activities, involving 10 social innovators of various areas (agricultural enterprises, real estate development and management companies, local initiative associations) gave evidence that the most serious obstacles for developing of their social idea was lack of knowledge how to attract investment, prepare project documents and attract society's attention to this problem. Most of the surveyed representatives (eight respondents) praised HEIs emphasizing that these were public institutions that they trusted most of all and that they had provided holistic assistance in giving consultations, helping to understand complicated legislative acts and showing true interest in project success. As a result of collaboration with university, one of the social innovators even had started up studies at the particular HEI because competent academic staff had convinced him about topicality of knowledge delivered in HEI that could be afterwards useful in social project management. In addition, three of the 10 interviewed project leaders claimed readiness to accept HEIs students for field practice in their project, thus providing transfer of their knowledge and showing interest in obtaining young people with specific up-to-date knowledge (e.g. in internetbased marketing research, digital marketing, e-commerce etc.) that they currently lack and that could be used to enhance their project visibility and scope, which in the authors' opinion is a positive trend and needs to be further developed and stimulated by programme directors of HEIs study programmes.

Indeed, higher education nowadays has a strong influence on solving social and economic problems and enhancing the development of national economy, which can be implemented by creation of social innovation. Scientists Liliana and Florina [9] emphasize that educational system directly supports the creation of social innovation. Moreover, history gives evidence that those countries that knew how to invest in education to broaden the access to preparation and to improve the educational and professional training standards have over time obtained the most spectacular and the most durable economic growths. These facts suggest that social awareness of each society individual is closely connected with higher education development and creation of social innovation. Accordingly, higher education institutions today cannot be regarded just as isolated institutions that elaborate and transfer knowledge to students, but rather the agents of changes $[9 ; 10]$. To ensure the transformation of intellectual and creative potential of humanity in innovative and competitive development of economy, it is necessary to revise the former model of education system. At present, the current system of education mainly focuses on individuals by shaping their abilities to independently and critically think, be creative, collaborate and adapt to various circumstances. However, insufficient attention is paid to strengthening students' overall social awareness so that the central values of the young generation would not be only associated with their personal success and self-actualization by accumulating wealth and get power over other people. Today it is more important than ever to create young generation's awareness of necessity to create such products and services that are needed in today's society and do not conflict with the principles of business ethics and sustainable development. Moreover, today sustainable development is related not only with sustainable production issues but also with sustainable consumption, which is often less attractive for young generation and does not give instant gratification. In authors' opinion, HEI's task is to develop and integrate in to study programmes such study courses that enhance students' social awareness and responsibility for the overall nation's economic development and welfare. In the reality, often the main interests of becoming accountants are focused on how to avoid taxes, while the becoming pharmacists are not interested to take holistic care for peoples' health, but rather to become sales managers of pharmacy companies and make profit for them thus earning good personal material bonuses. The becoming engineers and building constructors, in their turn, are not interested to stimulate building of safe and sustainable public buildings but to get high posts in public authorities to be able to make top deals with private sector and show personal power. Also in the eyes of becoming entrepreneurs and economists, participation in social projects is often not prestigious and is not taken seriously as a good practice. Thus, due to such attitude, social innovation development in Latvia is one of the lowest in the European Union [10].

In the previous theoretical studies conducted in scope of the project "Involvement of the Society in Social Innovation for Providing Sustainable Development of Latvia (EKOSOC-LV)", the researchers [5] have gained confidence that education has three important objectives in promoting social innovation processes in the society: 1) helping to identify social need; 2) causing interest in 
societal challenges; 3) motivating to improve the overall quality of life in the country thus strengthening its global competitiveness.

Lately, several HEIs in Latvia have already started to introduce in their study programmes such study courses as Social Entrepreneurship, Social Innovation, Social Marketing, Business Ethic, Bioeconomics, Sustainability Studies etc. The introduction of such courses is likely to increase social awareness of individuals, make them sensitive to problems in their environment, provide them with a chance to explore the right things, help them to create innovative solutions for the problems and support their ability of giving an opinion about created solutions. In addition to these individual achievements, it also has positive effects on society [11]. In authors' opinion, policy makers often consider that the integration of social awareness and social innovation ideas into HEIs study programmes is the main responsibility of social sciences, which, however, indicates a very narrow view of Latvia's range of problems. The authors' personal experience gives evidence that using of problem-based learning process is very helpful for involving students in creation of social innovation. Problem-based learning (PBL) is a student-centred pedagogy in which students learn about a subject through the experience of solving an open-ended problem found in trigger material. Even though PBL does not always bring a clear and defined solution to the problem, it allows for the development of desirable skills and attributes [12]. The major obstacles for implementation of PBL in higher education are lack of resources and competent academic staff facilitation. The authors' personal experience gives evidence that to involve students in shaping solutions for social problems, it is necessary to have at least few field work studies (e.g. visiting neglected areas, meeting with referent social groups), which requires additional financial resources (e.g. transportation facilities to the research objects are necessary). Moreover, it is highly advisable that students can practically meet with other already successful social entrepreneurs, which we are sorely lacking in Latvia. Thus, for academic teaching staff it is much easier to teach traditionally and, except personal self-actualization, they often have no other motivation to be engaged in the process of enhancing social innovation creation.

The above-described situation gives evidence that in Latvia social innovation creation from bottom-up is currently problematic and insufficiently promoted. Society, business people and HEIs use waiting tactics, expecting a push from somebody else - local municipality, relevant ministry, Latvia Investment and Development Agency etc.

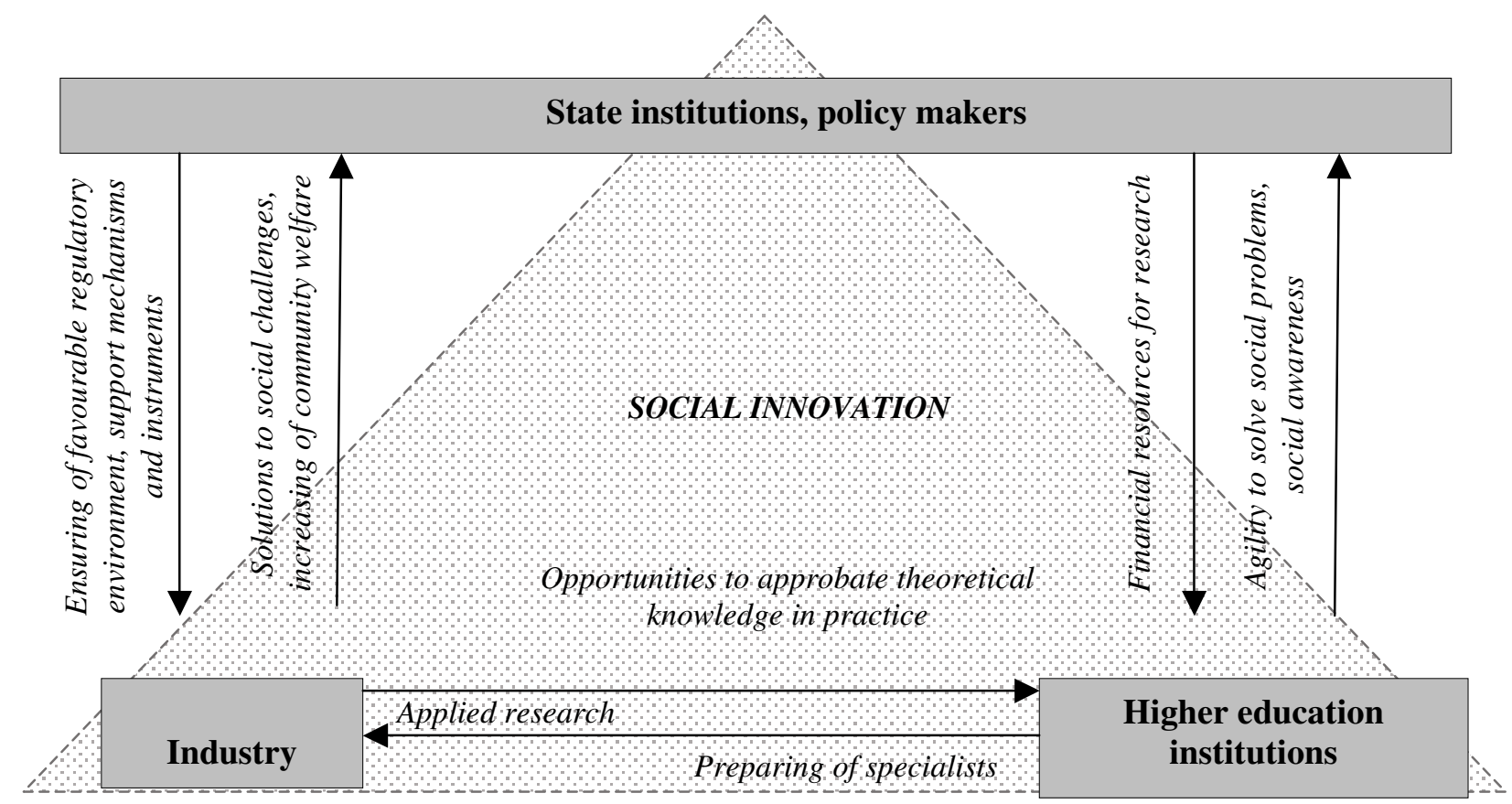

Fig. 1. Functional model of social innovation in LatviaSource: Dobele, Grinberga-Zalite, 2016

Based on the previous studies, the authors consider that enhancing of students' social awareness and their motivation to involve in creation of social innovation is possible through active interaction of the three stake holders: 1) industry representatives (e.g., agricultural enterprises that lack labour force 
in apple tree growing farms); 2) state institutions (relevant ministries, state agencies etc.); 3) HEIs that would be interested to integrate such collaboration in their study courses, field practice activities, scientific projects, bachelor and master's work themes (Figure 1).

\section{Conclusions}

1. The relevance of social innovation increases owing to the growing social needs and as an innovative solution for those issues that require structural changes to promote the welfare of the population and more efficient use of financial resources.

2. Social innovation is closely linked with the social economy development that could be defined as a third sector among economies between the private and public sectors, which is currently developing slowly in Latvia. Social innovation requires different and diverse set of support resources, including policy makers' recognition and support, and often is connected with volunteer work and charity.

3. One of the most serious drawbacks of social innovation development in Latvia is lack of specific knowledge how to attract investment, prepare project documents and attract society's attention to problems. Today, important task of HEIs in Latvia is to develop such study courses that enhance students' social awareness and responsibility about the nation's future development.

4. Since one third of the interviewed project leaders claimed readiness to accept HEIs students for field practice in their projects, programme directors of HEIs should actively work on enhancing cooperation between HEIs and social project implementers, which could enable students to approbate their academic knowledge in real projects that result in socially desirable products and strengthen students' social awareness and comprehension of social challenges that modern societies need to deal with.

5. The authors' study gives evidence that although the role of teaching staff to enhance the creation of social innovation is highly important, currently the most urgent need is to develop appropriate financial and information support tools for social innovation promoters and implementers, which would motivate them to cooperate and make this cooperation process standardized.

6. In Latvia, the Ministry of Economics is the relevant state administration institution in the field of economic policy as well as in implementing and developing innovation policy in the country. Therefore, it should take the initiative to create the legislative framework for promoting social innovation in Latvia that among other stakeholders would specify the role and objectives of HEIs in the enhancement of social innovation development.

\section{Acknowledgement}

The paper was elaborated in scope of the project "Involvement of the Society in Social Innovation for Providing Sustainable Development of Latvia" supported by the National Research Program 5.2. "Economic Transformation, Smart Growth, Governance and Legal Framework for the State and Society for Sustainable Development - a New Approach to the Creation of a Sustainable Learning Community (EKOSOC-LV)".

\section{References}

1. Dobele L., Grinberga-Zalite G, Kelle L. Sustainable economic development: scenarios for promotion of social innovation in Latvia. Journal of Security and Sustainability Issues. International Entrepreneurial Perspectives and Innovative Outcomes. - Vol. 5(2), 2015, pp. 149-158.

2. European Commission. Empowering people, driving change: Social innovation in the European Union. Bureau of the European Policy Advisers, European Commission, 2011.

3. Mulgan G., Landry L. The Other Invisible Hand: Remaking Charity for the 21st Century. London: Demos/Comedia, 1995.

4. Bonifacio M. Social innovation: A novel policy stream or a policy compromise? An EU Perspective. European Review, 22(1), 2014, pp. 145-169.

5. Surikova S., Oganisjana K., Grinberga-Zalite G. The role of education in promoting social innovation processes in the society. The Role of Education in Promoting Social Innovation 
Processes in the Society. In: Velta Lubkina and Svetlana Usca (Eds.), SOCIETY. INTEGRATION. EDUCATION. Proceedings of the International Scientific Conference, May 22nd-23rd, 2015, Volume IV, pp. 233-243, 2015, Rezekne: Rezeknes Augstskola.

6. Lukjanska R., Cirule I. Socialas uznemejdarbibas pamatnostadnes, labas prakses apkopojums un ieteikumi Latvijas pasvaldibam (Guidelines for social entrepreneurship, summary of best practices, and recommendations for Latvian municipalities). Socialas Inovacijas Centrs, 2014, $24 \mathrm{p}$.

7. Monzon J.M., Chaves R. The Social Economy in the European Union. Brussels: European Union, European Economic and Social Committee, 2012, p.118.

8. Social Innovation. European Commission, s.a. [online] [15.03.2017]. Available at: http://ec.europa.eu/social/main.jsp?catId=1022

9. Liliana D., Florina P.S., Education, Knowledge and Innovation from a Mechatronics Perspective, Procedia - Social and Behavioral Sciences, vol. 203, 2015, p. 205.

10. Dobele L., Grinberga-Zalite G. Opportunities of integrating social awareness in higher education to enhance the development of social innovation in Latvia. 16th International multidisciplinary scientific GeoConference SGEM 2016 : conference proceedings, Book 5 : Ecology, Economics, Education and Legislation, Vol. 3 : Environmental economics. Education and accreditation in geosciences, 2016, pp. 915-922.

11. Sarikaya M., Coskun E.A., New Approach in Preschool Education: Social Entrepreneurship Education, Procedia - Social and Behavioral Sciences, vol. 195, 2015, pp. 888-894.

12. Schmidt H.G; Rotgans J.I; Yew E. HJ. "The process of problem-based learning: What works and why". Medical Education. 45 (8), 2011, pp. 792-806. 